\title{
Runoff Analysis by Spreadsheet of the Pasak-Jolasid Dam Basin in Thailand
}

\author{
Katsuro Shioda ${ }^{1}$ and Hiroshi Itagaki ${ }^{2}$
}

\begin{abstract}
This paper describes a simple runoff analysis method by using only spreadsheet software (Excel) that allows counterpart personnel in developing countries to easily predict the amount of runoff to a dam. A case study was done for the Pasak-Jolasid dam basin which has a long and wide area and also has operation problems. A single runoff does not fill the reservoir. It is difficult to separate the runoff by each rainfall due to the long duration of runoff, and therefore period runoff (runoff for some duration) should be taken into account. It was found that the runoff duration is approximately one month. Runoff ratios should be calculated by this monthly runoff depth and the areal rainfall of the previous month. The rainy season and the dry season are clearly separated in the dam basin. There are two peaks of rainfall, one in May and the other one in August/September. Most of the rainfall percolates into dry soil at the start of the rainy season, so the runoff ratios are low. As the soil moisture increases, the runoff ratios increase and become highest in September, after which they decrease.
\end{abstract}

Keywords: Dam; Reservoir; Runoff analysis; Runoff ratio; Rainfall; Royal Irrigation Department; Thailand

\section{Introduction}

The Pasak-Jolasid Dam, which entered operation in 1999, is a multi-purpose dam that provides water for agriculture, consumption, and industry, helps mitigate flooding, and also serves as a recreational area. Construction of the dam was advocated by His Majesty the King of Thailand. The dam appears on the highest denomination banknote, 1,000 Baht, with the King, and is also the newest of the big dams in Thailand.

Operation and maintenance of the dam have been carried out by the Royal Irrigation Department (RID) who constructed it. The RID stored water in the dam in excess of the maximum water surface level for more than one month (from September 12 to 18 and from September 23 to October 17) in the flood season in 2002 (Figure 1). As a result, inundations occurred over a wide area in the dam basin and several schools had to close for a long period. In the last two years, especially during the dry season, water levels have been under the rule curve for a long time due to drought (Figure 1). This rule curve, which is used as the guideline for operation, corresponds to the lower rule curve.

One effective method for coping with such problems in operating the dam is to predict the quantity of inflow to the dam (runoff).

The purpose of this study was to analyze runoff ratios as a simple method of predicting inflow and thus operating the dam, to enable our counterparts to easily use and maintain the method.

This analysis is still being conducted as follows. A Japanese technical cooperation project named "The Modernization of Water Management System Project in Thailand" is studying runoff in the left bank area of the Chainat-Pasak

\footnotetext{
' Chief Advisor, Modernization of Water Management System Project in Thailand, Royal Irrigation Department, 811 Samsen Road, Dusit, Bangkok 10300, Thailand

${ }^{2}$ Professor, Faculty of Applied Biological Science, Gifu University, 1-1 Yanagido, Gifu 501-1193, Japan
}

main canal (the main canal) to evaluate and use side flow to the main canal (Sucharit et al., 2005). However, this study has some problems due to insufficient and inaccurate hydrological data. Therefore, as a reference for the study, the authors examined the tendencies of runoff in the dam basin which is adjacent to the left bank area of the main canal (Figure 2) because reliable data such as rainfall, etc. have been observed at many points in the dam basin and the amount of runoff in the dam basin has also been accurately observed as data on inflows to the dam.

\section{Configuration of the dam}

The configuration of the dam can be summarized as follows (RID, 1999).

Location of headworks: latitude $14^{\circ} 50^{\prime} 32^{\prime \prime}$ north and longitude $101^{\circ} 05^{\prime} 00^{\prime \prime}$ east (Figures 2 and 3 )

Dam type: zone type

Dam length: $4,860 \mathrm{~m}$

Dam height: $31.50 \mathrm{~m}$

Gated spillway: $71.00 \mathrm{~m}$ (width)

Auxiliary spillway: $3.00 \mathrm{~m}$ (diameter)

River outlet: $3.00 \mathrm{~m}$ (diameter)

Catchment area: $14,520 \mathrm{~km}^{2}$

River length from source to headworks: $380 \mathrm{~km}$

River slope at headworks: $1: 4,000$

Average annual rainfall: $1,250 \mathrm{~mm}$

Average annual rainy days: 109 days

Average annual reservoir inflow: 2,100 million cubic meters (MCM)

Crest level: +46.50 mean sea level (MSL)

Maximum water surface level: $+43.00 \mathrm{MSL}$

Retention level: $+42.00 \mathrm{MSL}$

Minimum water surface level: $+29.00 \mathrm{MSL}$

Reservoir capacity at maximum level: $960 \mathrm{MCM}$

Reservoir capacity at retention level: $785 \mathrm{MCM}$

Reservoir capacity at minimum level: $3 \mathrm{MCM}$ 


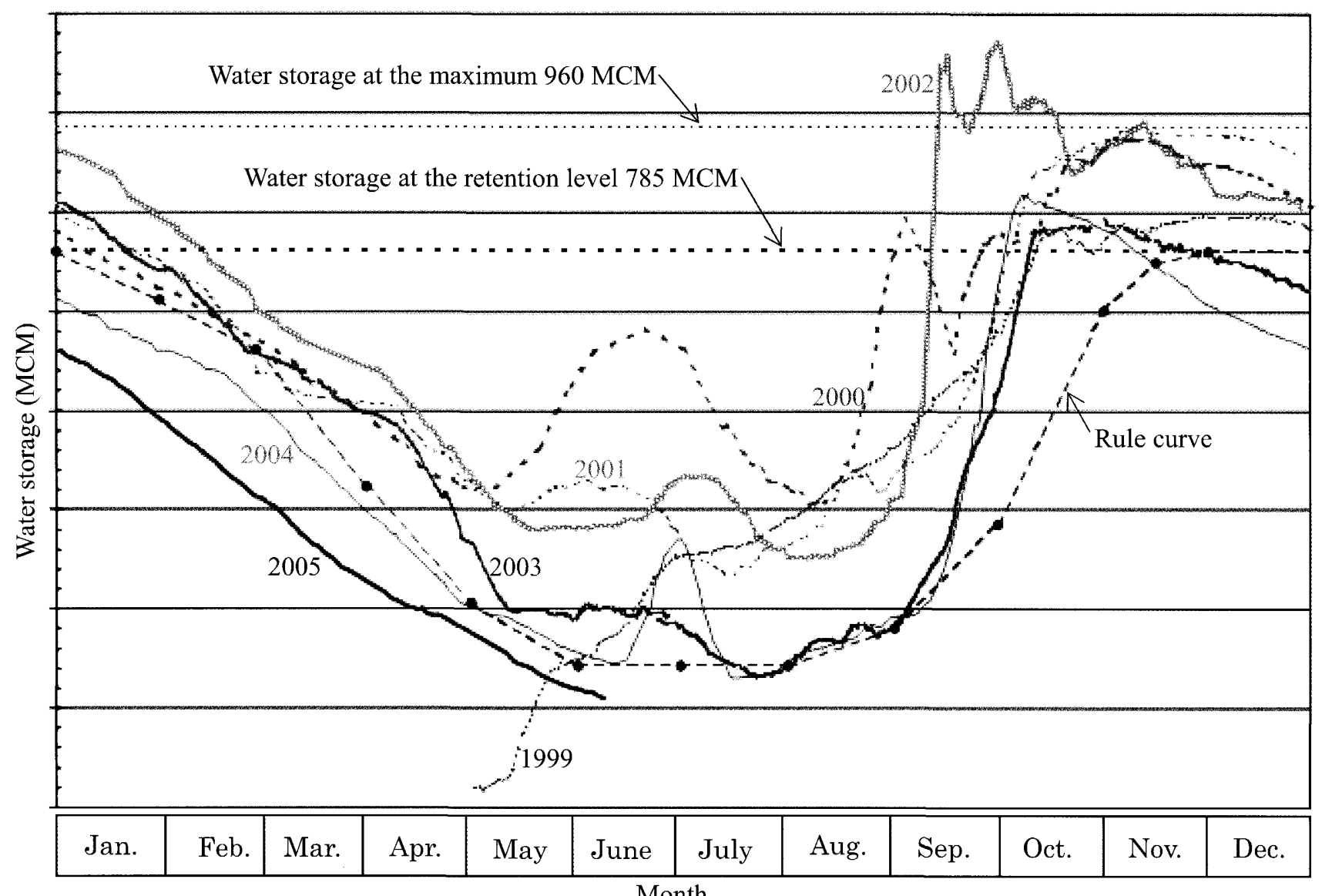

Figure 1: Water storage of the Pasak-Jolasid dam

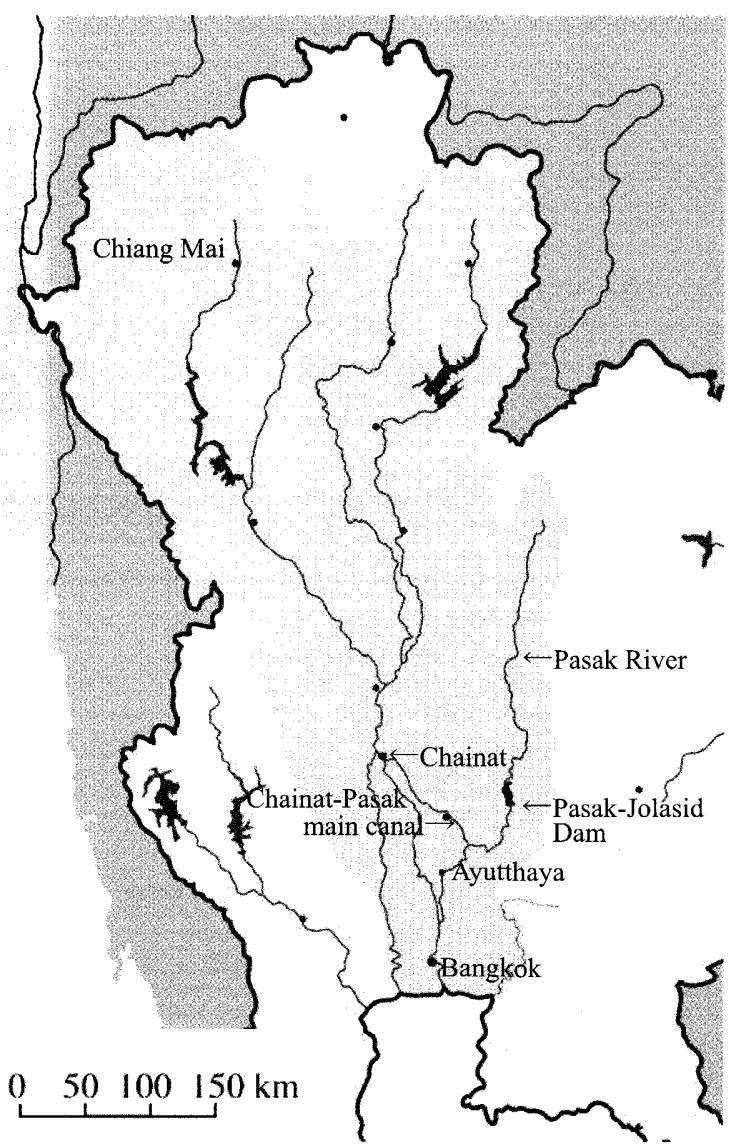

Figure 2: Locations of the Pasak-Jolasid dam and the Chainat-Pasak main canal

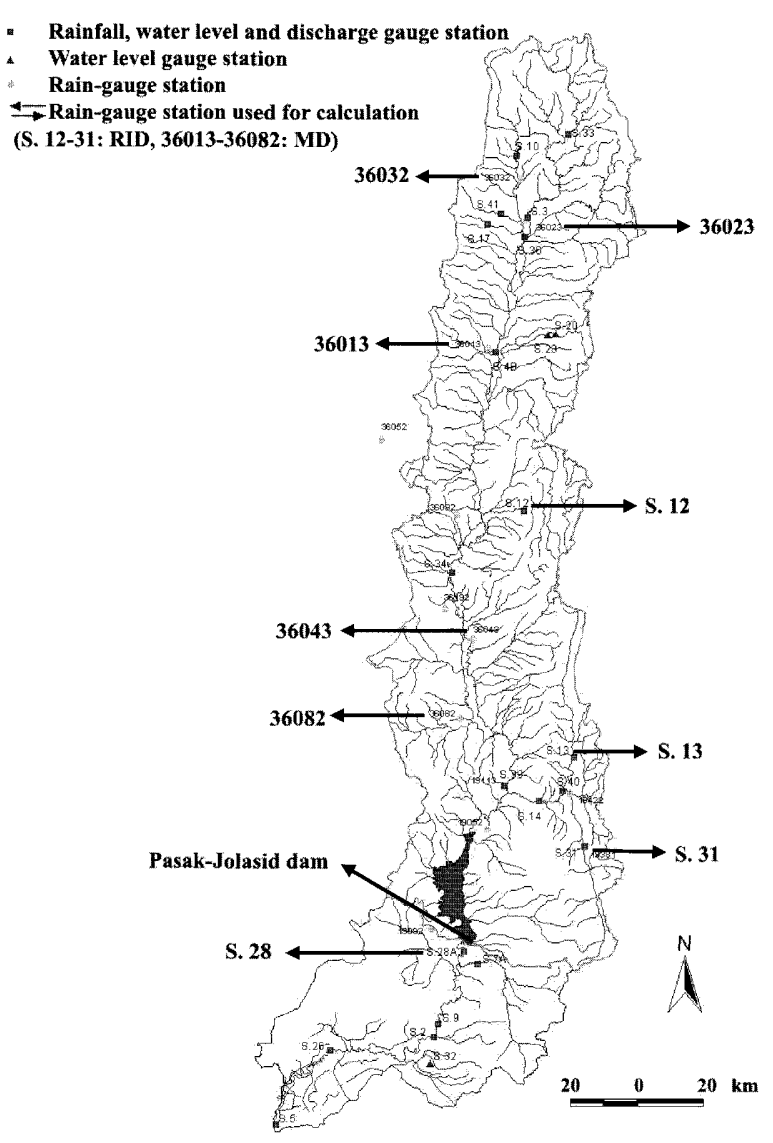

Figure 3: Pasak-Jolasid dam basin and rain-gauge stations 
Table 1: Land utilization of Pasak-Jolasid dam basin by province (Phetchabun), 1999 (Unit: Rai = 0.16 ha)

\begin{tabular}{|c|c|c|c|c|c|c|c|c|c|c|c|c|c|}
\hline \multirow{2}{*}{ Province } & \multirow{2}{*}{ Total land } & \multirow{2}{*}{$\begin{array}{l}\text { Forest } \\
\text { land }\end{array}$} & \multicolumn{10}{|c|}{ Farm holding land } & \multirow{2}{*}{$\begin{array}{l}\text { Unclassi- } \\
\text { fied land }\end{array}$} \\
\hline & & & $\begin{array}{l}\text { Number } \\
\text { of } \\
\text { house- } \\
\text { holds }\end{array}$ & $\begin{array}{l}\text { Hous- } \\
\text { ing } \\
\text { area }\end{array}$ & $\begin{array}{l}\text { Paddy } \\
\text { land }\end{array}$ & Field crop & $\begin{array}{l}\text { Fruit } \\
\text { trees and } \\
\text { tree } \\
\text { crops }\end{array}$ & $\begin{array}{l}\text { Vegeta- } \\
\text { bles and } \\
\text { flowers }\end{array}$ & $\begin{array}{l}\text { Grass } \\
\text { land }\end{array}$ & $\begin{array}{l}\text { Idle } \\
\text { land }\end{array}$ & $\begin{array}{l}\text { Other } \\
\text { land }\end{array}$ & Total & \\
\hline Phetchabun & $7,917,760$ & $1,519,032$ & 112,134 & 66,116 & $1,460,778$ & $1,944,159$ & 317,090 & 29,413 & 14,365 & 19,655 & 29,649 & $3,881,225$ & $2,517,503$ \\
\hline$\%$ & 100.0 & 19.2 & - & 0.8 & 18.4 & 24.6 & 4.0 & 0.4 & 0.2 & 0.2 & 0.4 & 49.0 & 31.8 \\
\hline
\end{tabular}

Source: Agricultural Statistics of Thailand, Crop Year 2001/02

Notes: 1 . Forest land is the land area still under forest cover.

2. Idle land is areas under heavy grass where no crops can be grown for a while.

3. Other land is roads, sidewalks, ditches, fishponds, ponds, and other areas in the farm.

4. Unclassified land is the balance of land area calculated as (Total land - Forest land - Farm holding land), and includes degraded national forest reserves, swamp land, sanitary district areas, municipal areas, railroads, highways, housing, public areas, etc.

\section{Land utilization of Pasak-Jolasid dam basin}

Table 1 shows the land utilization of the Pasak-Jolasid dam basin; $30 \%$ of the area in Lop Buri province is also included in the dam basin, but it accounts for only $13 \%$ of the dam basin and its land utilization is similar to that of Phetchabun province. Therefore, only the land utilization of Phetchabun province is shown in Table 1.

\section{Principle of analyses}

The method for forecasting runoff should be made as simple as possible for practical use:

1) It should be possible to perform the analysis using only spreadsheet software (Excel).

2) The method should use only the observation data of the RID and the Meteorological Department (MD) in the catchment area of the dam.

The method should use only the data of daily inflow to the dam observed from 1 July 1999. However, for rainfall, daily rainfall data from January 1999 should be used for grasping the rainfall pattern.

A total of 9 rain-gauge stations (4 of the RID and 5 of the MD) satisfy these conditions (see Figure 3 ). The arithmetic average of rainfalls at those stations is used as the areal rainfall in the whole catchment area because there are a sufficient number of stations evenly distributed.

3) In this paper, runoff ratio and runoff coefficient are defined as follows:

$$
\text { Runoff ratio }=D / R
$$

where $D$ is depth of runoff in some period and $R$ is areal rainfall in the previous period of the same duration

$$
\text { Runoff coefficient }=D s / R s
$$

where $D s$ is cumulative depth of runoff from May to November and $R s$ is cumulative monthly areal rainfall from April to October as a whole rainy season

The reasons for using the period runoff for the analysis, which is obvious if we see the calculation results shown later, are as follows:

(1) The capacity of the reservoir is larger than the quantity of a single runoff, and so a single runoff cannot fill the reservoir.

(2) The duration of runoff caused by a single rainfall is very long in this dam basin, and so it is difficult to separate the runoff by each rainfall.

\section{Calculation procedures and results}

\subsection{Determination of rainfall pattern from monthly areal rainfall}

Figure 4 shows the monthly areal rainfall from 1999 to 2004 and the monthly depth of runoff from July 1999 to

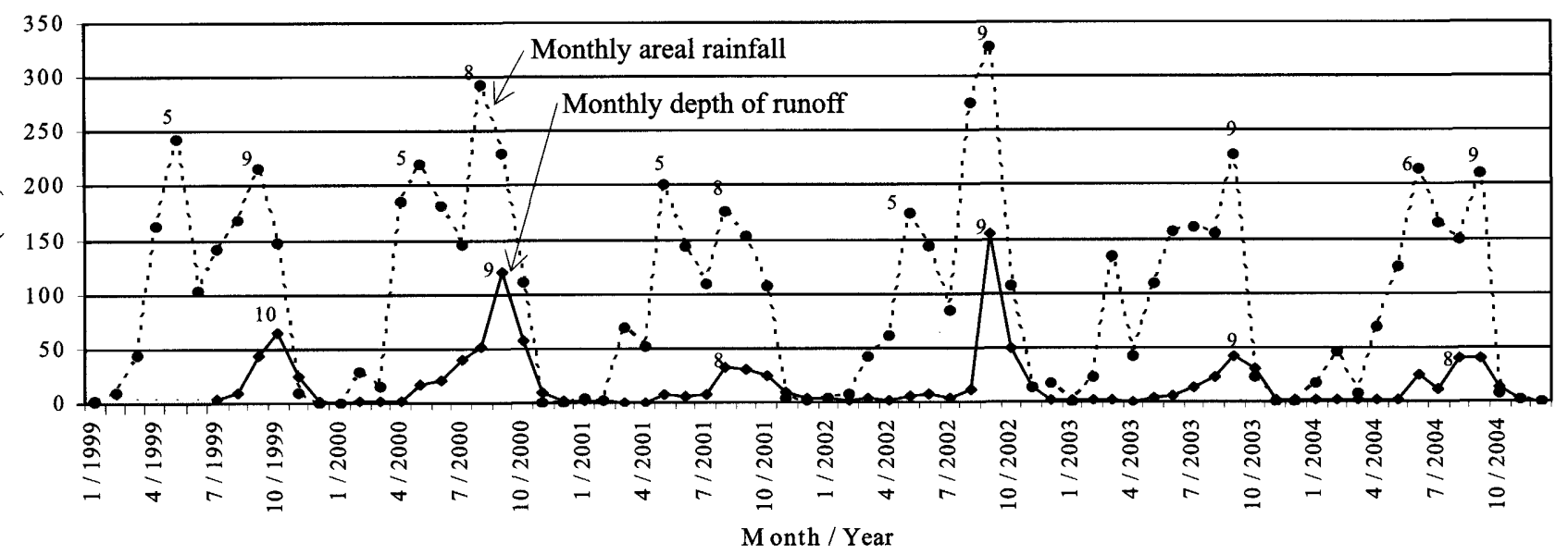

Figure 4: Monthly areal rainfall and monthly depth of runoff in the Pasak-Jolasid dam basin 


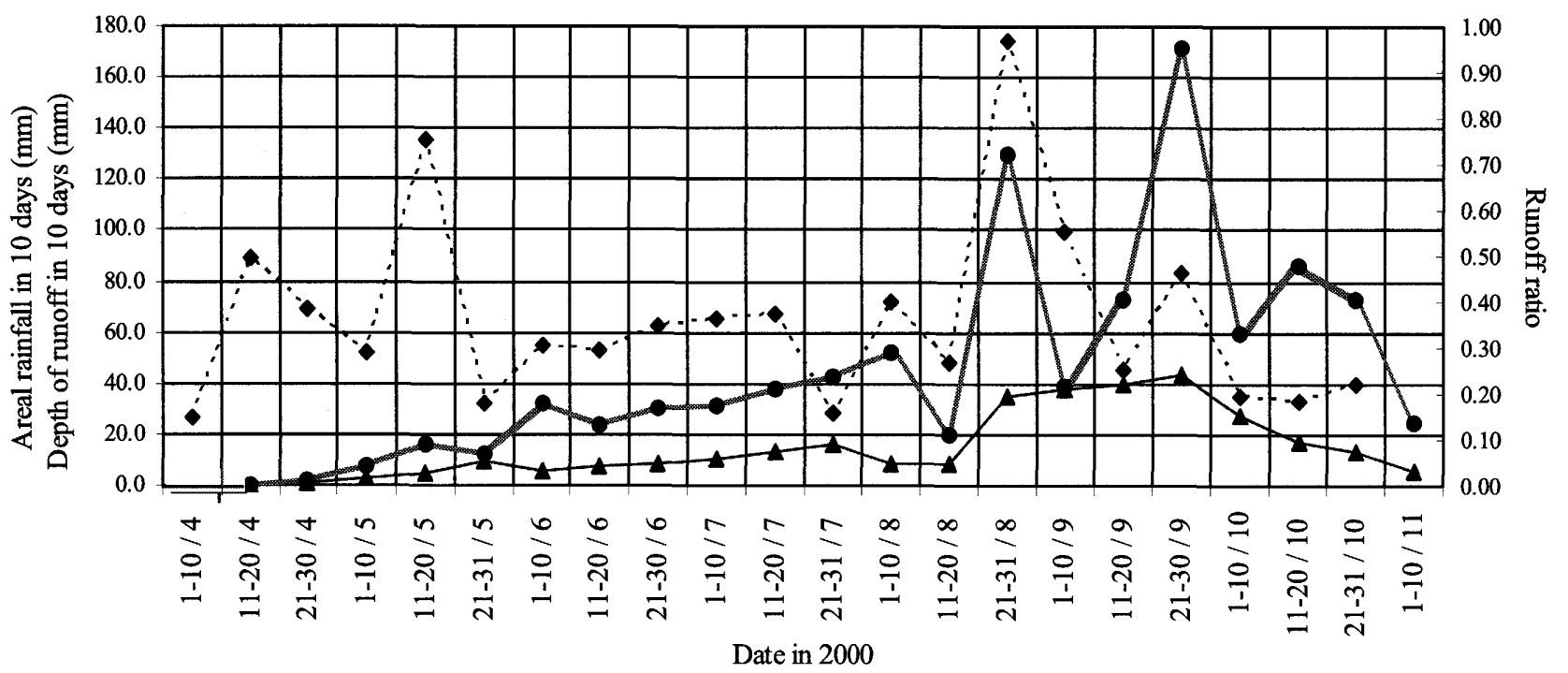

Date in 2000

$\cdots \bullet$ Areal rainfall in 10 days $\longrightarrow$ Depth of runoff in 10 days $\longrightarrow$ Runoff ratio

Figure 5: Areal rainfall, depth of runoff and runoff ratio in 10 days in 2000

December 2004. In Figure 4, the months in which peaks of monthly areal rainfall and monthly depth of runoff occurred are clearly shown. Rainfall is low in March and begins to increase mainly from April. It reaches its first peak in May, peaks again in August or September, then decreases and almost stops raining in November (in the middle of October 2003 and 2004 due to drought). Therefore, the rainy season is considered in this paper to be from April to October.

This rainfall pattern, with the rainy season from April to October and two peaks in May and August/September, is typical of the central plains and northern Thailand. In general, rainfall is higher in the later peak than the earlier peak.

\subsection{Determination of the time lag of runoff by compar-} ing daily runoff and daily rainfall in the rainy season An investigation of original data showed that the time lag of the peak runoff is about 10 days. However, in some cases it is more than 10 days at the start of the rainy season, whereas it is less than 10 days toward the end of the rainy season, and is just a few days in the case of heavy rain. The duration of runoff is rather long, and is sometimes more than one month (Figure 5).

Thus, calculations should be performed for both units of 10 days and 1 month.

\subsection{Calculation of runoff ratios}

The runoff ratios are calculated as follows.

1) Sum up the daily rainfall at each station to get the 10-day and monthly rainfall (mm/10-day and $\mathrm{mm} / \mathrm{month}$ ).

2) Calculate the 10-day and monthly areal rainfall in the basin: take the arithmetic averages of the 10-day and monthly rainfall at stations ( $\mathrm{mm} / 10$-day and $\mathrm{mm} / \mathrm{month}$ ).

3) Sum up the daily runoff (daily inflow data of the dam) to get the 10-day and monthly runoff (MCM/10-day and $\mathrm{MCM} /$ month).
4) Calculate the 10-day and monthly depth of runoff (mm/10-day and $\mathrm{mm} / \mathrm{month})$ : divide the result of step 3 ) by the basin area $\left(14,520 \mathrm{~km}^{2}\right)$ and multiply by 1000 .

5) Calculate the 10-day and monthly runoff ratio in each month: divide the result of step 4) by the result of step 2).

\subsection{Results for the 10-day unit}

The results of the calculation for the 10-day unit are shown in Figure 5 as a sample because the rainfall pattern was normal in 2000 .

As mentioned above, the time lag of peak runoff is approximately 10 days in the first half of the rainy season, e.g. the runoff depth during 21-31 May is derived from the rainfall during 11-20 May. In the latter half of the rainy season, the time lag of the peak runoff becomes less than 10 days, e.g. the runoff depth during 21-31 August is derived from the rainfall during the same period. However, the runoff duration becomes as long as approximately one month, e.g. the runoff depth from 21-31 August to 21-30 September is derived from the rainfall during 21-31 August.

Regarding the runoff ratios, in the first case, the runoff ratio during 21-31 May is low compared with the rainfall during 11-20 May, because the runoff depth during 21-31 May, which becomes the numerator in (1), is not so high even though the rainfall in the previous 10-day period, which becomes the denominator in (1), is very large. In another case, there are abnormally high runoff ratios such as 0.72 and 0.95 during 21-31 August and 21-30 September respectively considering that the runoff depths in these 10-day periods are slightly high even though the rainfall in the previous 10 days is rather low. The reason for those two cases is that the runoff of peak rainfall does not fluctuate so much, but is more steady due to the long runoff duration. Thus, the calculation results for the 1-month unit should be examined. 


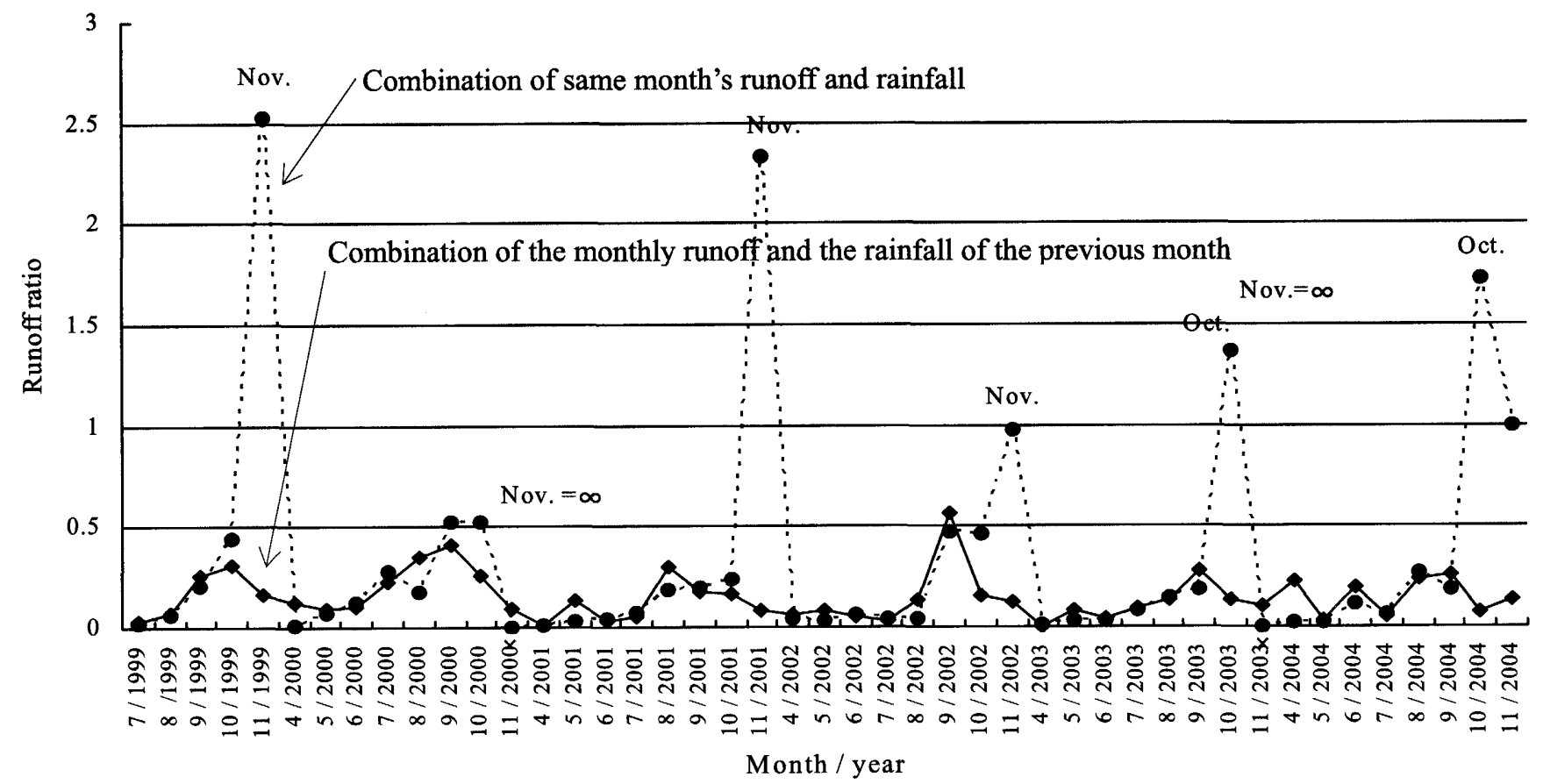

Figure 6: Monthly runoff ratios in combination of two cases

\subsection{Results for the 1-month unit}

\subsubsection{Rainfall and runoff into the dam}

Figure 4 shows the following.

The runoff peaks once around September whereas the rainfall peaks twice. This means that the soil at the start of the rainy season (May) is not saturated and so rainfall percolates into the soil easily.

Monthly rainfalls in November $1999-2002$ and October 2003 - 2004 are very small (almost zero); however, monthly runoff depths in these months are more than those. This is because the rainfall in the previous months continues to run off up to this month, thus proving that the runoff duration is as long as approximately 1 month.

Note that the monthly runoff to the dam is on the order of
$10 \mathrm{MCM} /$ month from April to May and $100 \mathrm{MCM} /$ month from June to July. It then increases dramatically in August to its peak in September, which becomes on the order of $1,000 \mathrm{MCM} /$ month in some years (2000 and 2002). After that, it decreases in October to become on the order of 100 $\mathrm{MCM} /$ month in November $(10 \mathrm{MCM} /$ month in 2003 and 2004 ), and finally returns to the order of $10 \mathrm{MCM} / \mathrm{month}$ in December, which are the values during the dry season.

\subsubsection{Monthly runoff ratio}

First, the runoff ratio calculated by the monthly runoff depth and the monthly rainfall of the same month is compared to the runoff ratio calculated by the monthly runoff depth and the monthly rainfall of the previous month (Fig-

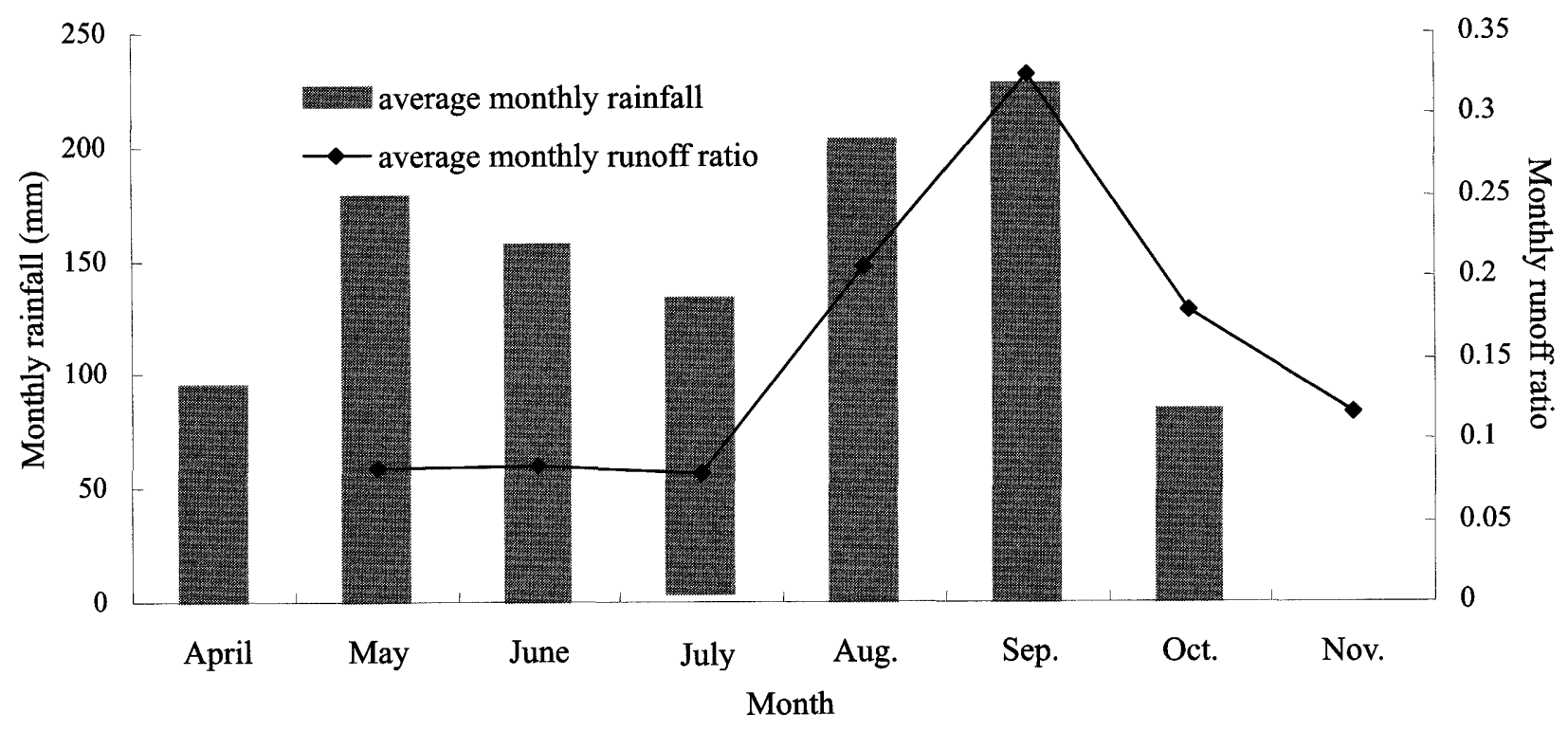

Figure 7: Average areal monthly rainfall and average monthly runoff ratio in the rainy season from 1999 to 2004 
ure 6). The latter one is obviously reasonable. The former one has unnaturally high runoff ratios of over 1.0. In Figure 6 , Nov. $=\infty$ means that in November rainfall as the denominator is zero but there is some amount of runoff as the numerator. Thus, the monthly runoff ratio should be determined by the fraction of the monthly runoff depth to the previous month's rainfall as mentioned before.

Figure 7 shows the average monthly runoff ratio (standard deviation: 0.111 ) and the average monthly rainfall in the 6 years from 1999 to 2004 . The runoff ratios are almost stable from May to July $(0.080-0.084)$, then rise and reach a peak in September. This is because, as mentioned earlier, a rather large amount of rainfall percolates into the dry soil in the first half of the rainy season and then the runoff increases in the latter half after the soil has become wet.

September is the most important month for dam operation because this is when the biggest runoff occurs. The authors calculated the equation relating the monthly runoff ratio in September and the monthly rainfall in August in order to predict the monthly runoff to the dam in September. As shown in Figure 8, the correlation coefficient is approximately 0.7 , showing a good correlation. Hence, the monthly runoff ratio in September can be calculated and so the amount of runoff in September can be approximately predicted. Regrettably, high correlations were not obtained for the other months.

\subsubsection{Runoff coefficient}

The runoff coefficient for the whole rainy season is calculated by (2).

We cannot use the data in 1999 for analyzing the runoff coefficient due to unknown values of the monthly depth of runoff in May and June. The results analyzed by using the five-year data from 2000 to 2004 are as follows.

It is interesting to note that the runoff coefficients are clearly distinguished between whether the cumulative rainfall in the rainy season is more than or less than approximately $1,000 \mathrm{~mm}$ (Table 2). When more than $1,000 \mathrm{~mm}$, the runoff coefficients are between 0.210 and 0.234 (average: 0.222 ) and when less than $1,000 \mathrm{~mm}$, they are between 0.125 and 0.140 (average: 0.134 ). The deflection widths are small.

Peak rainfalls in August or September in 2001, 2003 and 2004 with small runoff coefficients in these years are small. On the contrary, peak rainfalls in 2000 and 2002 with large runoff coefficients are large. Thus, it can be reasonably assumed that if heavy rain occurs during August and September when the soil is moist, the runoff will become high.

\section{Conclusions and recommendations}

The runoff analysis was done for a very long and wide catchment area in which the rainy season and the dry season are clearly separated.

1) A single runoff does not fill the reservoir and the runoff

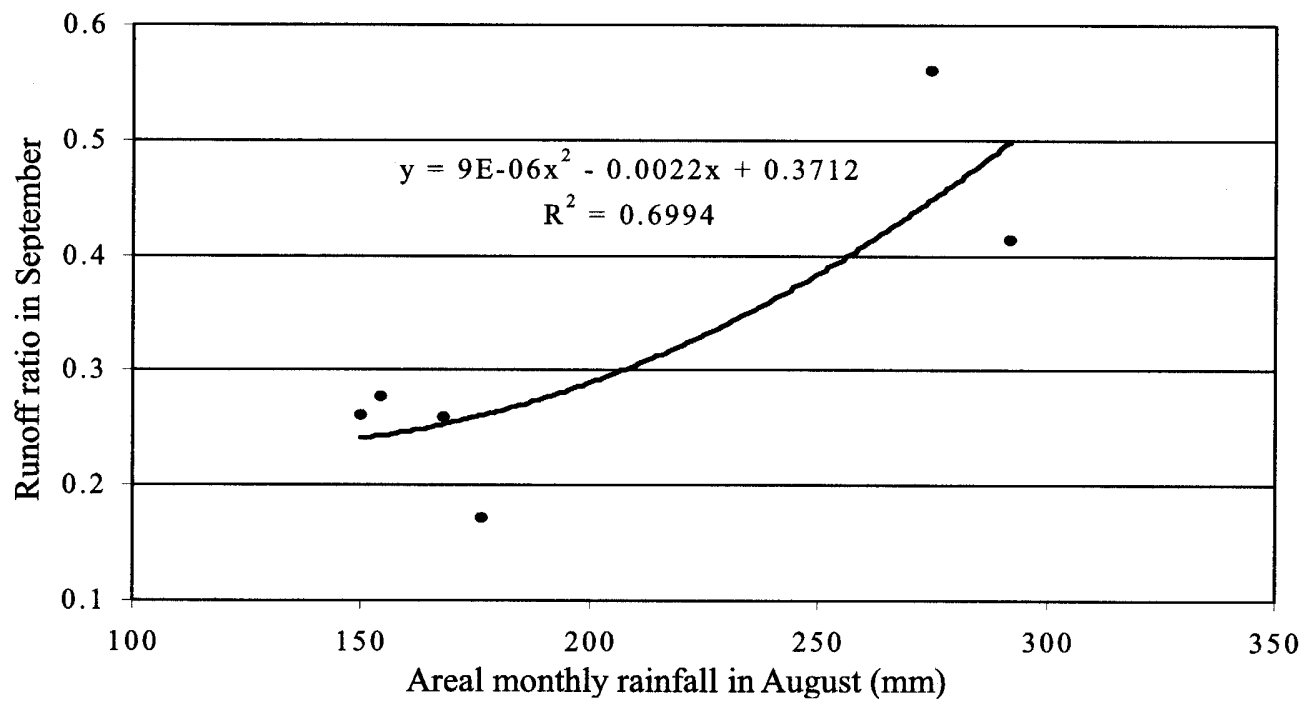

Figure 8: Equation for estimating the monthly runoff ratio in September from the monthly rainfall in August

Table 2: Runoff coefficient in the rainy season

\begin{tabular}{|l|c|c|c|c|c|c|}
\hline \multicolumn{1}{|c|}{ Year } & 2000 & 2001 & 2002 & 2003 & 2004 & Average \\
\hline $\begin{array}{l}\text { Cumulative rainfall in } \\
\text { the rainy season (mm) }\end{array}$ & 1363.1 & 942.3 & 1169.9 & 874.7 & 939.3 & 1057.9 \\
\hline A: runoff coefficient & 0.234 & & 0.210 & & & 0.222 \\
\hline B: runoff coefficient & & 0.125 & & 0.138 & 0.140 & 0.134 \\
\hline
\end{tabular}

Notes: A: cumulative rainfall $\geq 1,000 \mathrm{~mm}$

B: cumulative rainfall $<1,000 \mathrm{~mm}$ 
duration is very long. Therefore, it was found that period runoff should be taken into account for the runoff analysis, and that one month was proper for this period.

2) The authors developed an easy method of runoff analysis by using only Excel.

3) The authors specified monthly runoff ratios by simple statistical treatment such as an arithmetic mean and multiple regression analysis, allowing the next month's runoff to be forecast from this month's areal rainfall.

4) This method enables the runoff to be approximately predicted for the next month, and so is practical for water management, flood forecasting, effective use of runoff and so on.

Empirical results showed that most of the rainfall percolates into the dry soil at the start of the rainy season, so the runoff ratio is low. As the moisture in the soil increases, the runoff ratio increases. It becomes the highest in September and then decreases. Second, the runoff coefficient in the whole rainy season varies greatly due to differences in the total amount of rainfall and rainfall pattern. In areas where the rainy season and the dry season are clearly separated, if the total amount of rainfall is large and it rains a lot in the latter half of the rainy season, then the runoff coefficient will become high, and in case of the reverse it will become relatively low.

In this analysis, the authors used data of only six years. Therefore, it is recommended that the RID should perform further analyses by adding new data in order to raise the accuracy.

We hope this analysis method and results will be useful not only for the dam but also for similar basins.

\section{Acknowledgements}

The authors express their gratitude to the counterparts of the MWMS project for providing data, Dr. Shioda's secretary Miss Themjai for her assistance with data processing, and the Japanese experts Dr. Takaki and Mr. Horikawa for their advice.

\section{References}

[1] Royal Irrigation Department (1999): Pasak River Basin Development Project Initiated by H.M. the King, Leaflet of the project.

[2] Sucharit Koontanakulvong, Katsuro Shioda, Wongwatana Sombunying and Atthaporn Buddhapalit (2005): Runoff Characteristics in the left bank of Chainat-Pasak Canal, Journal of Hydrologist Assembly, Volume 10, pp.189-200.

Discussion open until December 31, 2006 